TEME, г. XLII, бр. 4, октобар - децембар 2018, стр. 1405-1418

Прегледни рад

Примљено: 26. 2. 2018.

DOI: $10.22190 /$ TEME1804405P

Ревидирана верзија: 19. 3. 2018.

Одобрено за штампу: 12. 6. 2018.

\title{
СРПСКА ПРАВОСЛАВНА ЦРКВА \\ КАО КОМУНИКАЦИОНИ АГЕНС ${ }^{a}$
}

\author{
Јасна Парлић Божовић $^{1 *}$, Драгана Божовић ${ }^{2}$ \\ ${ }^{1}$ Универзитет у Приштини, Филозофски факултет у Косовској Митровици, \\ Косовска Митровица, Србија \\ ${ }^{2}$ Универзитет у Београду, Факултет политичких наука, Београд, Србија \\ *jasna.parlic.bozovic@pr.ac.rs
}

\begin{abstract}
Апстракт
Од самог рођења, религија има важну функцију у животу сваког човека. У зависности од културе, религијске норме и вредности различито су интерпретиране и усађиване кроз процесе социјализације припадницима једног друштва. Кроз историју се начин на који су људи сазнавали религијску поруку мењао. Нове технологије утицале су на појављивање нових медија - канала комуникације, што је утицало и на саму форму религијске поруке, односно на начин како ће она бити обликована, саопштена и интерпретирана. Религија је била значајна и за само стицање писмености међу Јужним Словенима. Њена реч преношена је како усменим путем тако и преко писаних, а затим и штампаних, књига, часописа и публикација. Даљим развојем технологија, односно стварањем електронских медија, верска порука добијала је облик прилагођен новим каналима комуникације. Последњи медиј који је, рекло би се на револуционаран начин, изменио поимање религијског учења јесте интернет. Уједно са овим процесом, отворена су и нека нова питања, почевши од оног најбаналнијег је ли религији место у онлајн верзији, па до нијанси где се неумитност религијског интернет постојања не доводи у питање, већ се покушава наћи одговор на питање како максимално искористити могућности интернет везе за одувек дефинисане функције религије. Глобални тренд паралелног живота у онлајн простору није заобишао ни нашу земљу. Тако су свој простор заузеле и институције Српске православне цркве. Поред постојања званичних сајтова, друштвене мреже попут Фејсбука, Твитера и других, постале су подједнако лепо место за онлајн религијски живот у Србији. Овај ће рад бити покушај за дефинисање стила који ће омогућити опис начина на који је Српска православна црква кроз историју прилагођавала своје поруке новим каналима комуникације и какав је облик црквена реч имала на почецима религијске самосвести, како се развијала и какав је њен облик у ери „онлајн самосвести”. Кроз такав приказ, циљ
\end{abstract}

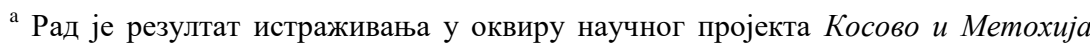
између националног идентитета и евроинтеграција, евиденциони број III 47023, који финансијски подржава Министарство просвете, науке и технолошког развоја Републике Србије.
} 
овог рада је да покаже каква је функција Српске православне цркве као важног агенса информационо-комуникационог система.

Кључне речи: религија, Српска православна црква, комуникација, комуникациони канали, интернет.

\title{
THE SERBIAN ORTHODOX CHURCH AS AN AGENT COMMUNICATION1 LANGUAGE
}

\begin{abstract}
Since early childbirth, religion has an important function in the life of every human being. Depending on culture, religious norms and values differently are interpreted and deeply embedded into the members of one society through a process of socialization. The way people practice their religion is changing through history.

The way individuals relate to and practice a religion changes over the course of time. New technologies have influenced on the appearance of new media - the communication channels, which has also affected the very form of the religious message, that is, how it will be designed, communicated and interpreted.

Religion was important for acquiring literacy among the South Slavs. Its word was conveyed verbally as well as throughout printed books, magazines and publication. By the further development of technologies or creating electronic media, the religious message has been received a form adapted to the modern communication channels.

It can be said in a revolutionary manner that the internet as the last medium changed the way of understanding or perception of religious learning. At the same time, some new issues have been opened, starting from the most banal, will the Internet itself ever serve as a source of the sacred or spiritual, till to the nuances where the inevitability of religious internet existence (Internet-based religion) should not be prejudged, but it is already trying to find the answer to the question of how to maximize the use of internet connectivity for the ever-defined function of religion.

The Internet has profoundly shaped our world and has changed our lives. The global trend of a parallel life in the internet (or using the internet) did not bypass our country. Thus, the institutions of the Serbian Orthodox Church took up their place. Despite the existence of official websites, social networks such as Facebook, Twitter and others, they are considered as an equally nice place for online religious life in Serbia and they are engaged in religious practices.

This paper will be an attempt to define a style that will provide a description of the manner in which the Serbian Orthodox Church through the history has adapted its messages to new channels of communication and what form the church word had at the very beginnings of religious self-awareness, its development over time and what is its form in the era of "online self-awareness". Through such a view, the aim of this paper is to show what is the function or role of the Serbian Orthodox Church as an important agent of the information and communication system.
\end{abstract}

Key words: religion, the Serbian Orthodox Church, communication, communication channels, the internet. 


\section{РЕЛИГИЈА И КОМУНИКАЦИЈА}

Реч религија потиче из латинског језика од речи religare, religio и religere. Religare се односи на нешто што је обавезујуће, religio указује на ограничење које се не може избећи, a religere на неизбежну пресуду која долази ван домета наше контроле (Brown, 1973: 3). Сумирајући ове изразе, Браун закључује да се значење речи религија односи на нешто од чега не можемо побећи и чему смо дубоко посвећени (Brown, 1973: 4). За разлику од њега, Дејвид Морган у својој књизи The Sacred Gaze: Religious Visual Culture in Theory and Practice, религију види као конфигурацију друштвених међуодноса и културних слојевитости које су усмерене ка силама које асистирају људским бићима у организовању њихових колективних и индивидуалних живота (Morgan, 2005: 5).

Водећи се српским речником у издању Вујаклије, „религија (лат. religio) представља учење које се тиче највишег бића (божанства, бога); вера; вероисповест; фиг. светиња; етичко начело којим је неки човек дубоко прожет, савест, ствар савести" (Вујаклија, 2006: 227). Иако нема општеприхваћене дефиниције религије, те различити аутори наглашавају значај појединих елемената, њено значење указује на постојање одређене везе између човека и Бога, односно човека и оног што се сматра натприродним, духовним, светим.

Ради успостављања такве везе, религије су одувек употребљавале одређене симболе, предмете, филозофске системе, митове. Циљ је био да се религијска порука што ефикасније пренесе до верника̂, односно помоћу ње допре до оног што се сматра натприродним. Враћајући се на саме почетке повезивања људи са оностраним, од паганских друштава, политеистичких, а онда и монотеистичких, религија је увек причала неку причу. Од врата до врата, мисионарством, а некада и средствима принуде циљ је био саопштити религијску поруку што већем броју људи, научити људе да верују, да се моле, да успоставе везу са Богом и организују своје животе у складу са религијским учењем.

Данас се повезаност између људског бића и Њега, углавном, не остварује на непосредан начин, већ посредством религијских организација које имају две основне функције: „прва је успостављање везе верника са Богом помоћу ритуала ${ }^{1}$ као што су крштење, причешће и други облици приступа светој тајни, а друга се остварује међусобним повезивањем њених припадника - верника" (СтојковићРадојковић, 2009: 108). Управо ову другу функцију наглашава Емил Диркем када говори о религији као извору друштвене солидарности

${ }^{1}$ Света Тајна у православљу не може бити „ритуал”, већ нешто уистину живо и истинито. 
и кохезије. Према њему је она „колективна ствар која служи да поново створи осећање заједништва у друштву кроз процес комуникације којим се религијска порука преноси до људи" (Dirkem, 1977: 75).

Ово говори о томе да је религија увек доживљавана и практикована унутар одређеног друштва (заједнице) унутар кога су и њене вредности интерпретиране у складу са историјским и друштвеним кретањима. Савремено друштво карактерише свеприсутност медија. На ту чињеницу указује и Стјуарт Хувер у књизи Religion in the Media Age: „Како све више залазимо у двадесет први век, тако се чини да се религија и медији све више повезују. Велики део савремене религиозности и духовности сазнајемо управо преко медија" (Hoover, 2006: 1). Ово скреће пажњу на околност да религија није могла да игнорише развој медија и тако остане на интерперсоналној комуникацији. Верске организације схватиле су да користећи медије могу значајно утицати на ставове људи и тиме остварити једну од својих основних функција ширења религиозности. Заправо, медијска видљивост постала је услов религијске видљивости и релевантности. На то скреће пажњу и Хјардвар када говори о „медијизацији религије” као процесу кроз који су се медији развили у једну независну друштвену институцију, а истовремено су почели да постају саставни део функционисања осталих институција, као што су породица, политика и религија (Harvard, 2008: 5). Као резултат тога, религија се све више подводи под логику медија, који постају примарни извор религијских идеја (Исто).

Религијске организације у том процесу добијају улогу важног агенса информационо-комуникационог система. Њихов значај огледа се у поверењу које уживају и ауторитету да усмеравају животе својих верника̂ у складу са религијским учењима. Зарад остварења тог циља, једна од основих функција религијских организација је комуникациона - да религијска порука добије одговарајућу форму како би се њено значење пренело и било декодирано као разумљиво, пријемчиво, а на крају и утицало на ставове оних којима се шаље. Стога, верске организације представљају значајне комуникационе агенсе у друштву.

„Комуникациони агенси јесу друштвене институције и друштвене групе, које - захваљујући својој важности за систем као целину, или својој улози унутар информационо-комуникационог система, имају активну улогу у процесу друштвеног комуницирања, односно имају способност да било вертикално (кроз читав глобални систем) било хоризонтално (унутар поједних подсистема) иницирају, усмеравају или спречавају комуникационе процесе" (Стојковић-Радојковић, 2009: 43).

У хришћанској традицији таква организација је црква, која представља заједницу верникаิ међусобно повезаних обичајима, веровањима, традицијом, присношћу, поверењем. Православну цркву 
чини систем помесних цркава које су аутокефалне, односно самосталне. Српска православна црква своју аутокефалност стиче 1219. године. Она данас игра активну улогу агенса информационо-комуникационог система стално усавршавајући и прилагођавајући се новим технологијама у процесу преношења порука верницима.

\section{ИСТОРИЈСКИ ПРИКАЗ НАЧИНА КОМУНИЦИРАЬА СРПСКЕ ПРАВОСЛАВНЕ ЦРКВЕ СА ВЕРНИЦИМА}

Настанак писма представља основу за почетак примања хришћанства на просторима Јужних Словена. Прве речи које су уопште написане на словенском језику и писму у 9. веку биле су речи Светог писма, које је са грчког језика превођено на словенски: „У почетку створи Бог небо и земљу. А земља беше празна и пуста, и беше тама над безданом, и дух Божји лебдео је над водама" (Даничић, 2005: 1).

Црквене књиге представљале су основу на којој се развијао књижевни језик. На нашим просторима браћа Ћирило и Методије су преводом литургијских, богослужбених и библијских књига поставили темеље словенској писмености, да би затим њихови ученици Климент и Наум саставили садашње српско писмо - ћирилицу. Важно је напоменути и да је од пресудног значаја за учвршћивање хришћанства међу Србима пре Светог Саве било то што су богослужења и проповеди вршене на народном језику, који је био разумљив народу. Дакле, паралелно са ширењем вере, одвијао се процес ширења писмености.

Када говоримо о Српској православној цркви, она је од давнина играла веома значајну улогу на историјској позорници нашег народа. Њена комуникациона димензија пратила је развој канала (медија) за преношење порука. Настанком телеграфа, телефона, радија, телевизије, а онда и интернета, црквена реч добијала је облик погодан за ове медије и на тај начин се брже и ефикасније преносила народу.

Настанак штампарије представља историјску прекретницу, чиме су се створили предуслови да, до тада руком писане, књиге почну да излазе на много бржи и једноставнији начин. Тако је и доступност црквених материјала постајала боља, а књиге јефтиније, што је олакшало комуникацију верника̂ и цркве.

О значају који је заузимала религија говори и чињеница да је прва одштампана књига била Свето писмо из 1455 . године, познатије као Гутенбергова Библија (Стојковић-Радојковић, 2009: 111). Код нас прва српска штампарија почиње са радом на Цетињу и 4. јануара 
1494. године одштампана је прва књига на српском језику - „Октоих првогласник” Ђурђа Црнојевића и штампара Макарија. ${ }^{2}$ То је уједно једна од највише коришћених богослужних књига у Српској православној цркви.

Повезаност религије и језика бива настављена и касније, па тако преводи Старог и Новог завета Ђуре Даничића и Вука Караџића у XIX постављају норме савременог српског књижевног језика. У том веку, тачније 1868. године, Српска православна црква почиње да издаје своје билтене и публикације у Београду и Новом Саду (Стојковић-Радојковић, 2009: 122). У јавно и масовно комуницирање укључује се тек 1967. године, од када издаје своје недељне новине „Православље" (Ибид).

Свака институција унутар Српске православне цркве сама одређује да ли ће и која средства информисања имати. Када говоримо о штампаним публикацијама, СПЦ поседује и службени гласник под називом „Гласник Патријаршије”, те публикације које издају епархије, као што је часопис „Искон Врањске епархије”, или локалне цркве попут мултимедијалног пројекта „Саборник”, који је покренула Саборна црква у Београду (Стојковић-Радојковић, 2009: 123). Ту су и часописи „Сагласје” Нишке епархије, „Православни мисионар” и „Земља живих”, који издаје Информативно-издавачка установа Светог архијерејског синода СПЦ, часопис „Каленић” Шумадијске епархије и други.

\section{ПРИСУТНОСТ ЦРКВЕ У ЕЛЕКТРОНСКИМ МЕДИЈИМА}

Даљим напретком комуникационих технологија, односно појавом радија, створили су се предуслови за другачије форме комуницирања. На простору бивше Краљевине Југославије почеци радиопрограма везују се за период између двадесетих и тридесетих година прошлог века. Ту је свакако највећи значај имао Радио Београд. Поред многобројних емисија и прилога верске садржине, Радио Београд је као своју традицију увео преношење свете литургије из Саборне цркве и Цркве Светог Марка за време недељних литургија и највећих православних празника.

Већ крајем четврте деценије двадесетог века Српска православна црква постаје жртва тада актуелног тоталитарног атеистичког режима. Над свим активностима ове институције спровођена је оштра цензура. И док јој је приступ радију и телевизији био у потпуности онемогућен, о свом трошку Црква је могла да штампа новине и

2 Погледати више на: http://www.poreklo.rs/2013/01/04/na-dana\%C5\%A1nji-dan\%С5\%A1tampana-prva-knjiga-na-srpskom-oktoih-prvoglasnik/, приступљено: 20. 8. 2016. године. 
публикације (Стојковић-Радојковић, 2009: 121). Упркос формалној дозволи, у стварности су забрањиване књиге и часописи верских садржаја, а притисак који је вршен од стране режима огледао се и у забрани посећивања храмова, дискусијама о вери на јавном месту и пропагирања религијских начела. За Српску православну цркву, овај период је представљао „Мрачни средњи век” типичан за готово миленијумску стагнацију културе и уметности у Европи после пада Рима 476. године. Тек са напуштањем марксистичке идеолошке матрице, СПЦ добија више простора за деловање помоћу медија, али се она и даље не експонира много у јавном и масовном комуницирању, а што је делом последица слабијег материјалног стања, јер православци не убирају на литургијама, или на други начин, новац за своја средства информисања (Стојковић-Радојковић, 2009: 121).

Након овог тешког периода, Црква поново добија могућност за медијско комуницирање, па тако 25. фебруара 1998. године епархијски Управни одбор Митрополије Црногорско-приморске доноси одлуку о оснивању радија. После опсежних припрема, Радио Светигора почиње да емитује програм 7. јуна исте године. ${ }^{3}$ Тиме је Српска православна црква добила своју прву радио-станицу и први пут се у процесе масовног комуницирања укључила преко електронског медија под њеном патронатом. ${ }^{4}$

Као једна од најзначајнијих могућности званичног информисања човека 20-ог и 21-ог века, и телевизија је послужила као средство ширења религијских порука приказујући масовна окупљања верника̂ у црквама и манастирима за време празника. Коришћена је и за званично обраћање верских поглавара, пре свега партријархаิ, а затим и осталих владика̂ и црквених великодостојника̂, затим за информисање ширих слојева народа о верским начелима, посту и празницима. Неке од емисија које су искључиво специјализоване за религиозне садржаје су, између осталог, „Духовници” и „Агапе” на телевизији Студио Б, као и „Верски календар” на другом програму РТС-а.

\footnotetext{
${ }^{3}$ Погледати више на: http://www.svetigora.com/istorijat, приступљено 25. 8. 2016. године.

${ }^{4}$ Црквена реч данас иде у етар кроз деловање следећих радио-станица: Радио Светигора, Цетиње, Митрополија црногорско-приморска; Радио Искон, Врање, Епархија врањска; Радио Слово љубве, Београд, Архиепископија београдско-карловачка; Радио Источник, Ваљево, Епархија ваљевска; Радио Православље, Суботица, Епархија бачка; Радио Беседа, Нови Сад, Епархија бачка; Радио Златоусти, Крагујевац, Епархија шумадијска; Радио Глас, Ниш, Епархија нишка; Радио Земља живих, Нови Сад, Епархија бачка; Радио Благовесник, Сомбор, Епархија бачка; Радио Српски Сион, Рума, Епархија сремска; Радио Манастир Лепавина, Лепавина, Митрополија загребачко-љубљанска; Радио Манастир Подмаине, Подмаине, Митрополија црногорско-приморска; Радио Глас Цркве, Шабац, Епархија шабачка. ${ }^{4}$
} 
Законом о електронским медијима из 2014. године црквама и верским заједницама дата је могућност да медијску услугу пружају у оквиру регионалне, а не само локалне зоне покривања, на коју су раније били ограничени. Према овом закону, дозвола за пружање медијске услуге цивилног сектора, у који су сврстане и цркве и верске заједнице, издаје се без обавезе плаћања накнаде. ${ }^{5}$ Тако за Божић 2015. године креће са радом Телевизија Храм. Иако је она у многим медијима представљена као прва телевизија Српске православне цркве, две телевизије добиле су 2008. и 2009. године дозволу тадашње Републичке радиодифузне агенције (РРА) за емитовање телевизијског програма на локалном подручју: ТВ „Беседа” Епархије бачке, која је тек требало да почне са радом, и ТВ „Логос” Епархије жичке, која је постојала од 2004. године. ${ }^{6}$ Обе су, међутим, вратиле дозволу 2012. године јер нису успеле да покрену програм.

Садржај Телевизије Храм гледаоци могу пратити само путем интернета, што уједно указује на значајност овог медија.

\section{ИНТЕРНЕТ И СРПСКА ПРАВОСЛАВНА ЦРКВА}

У ери у којој приступ интернету постаје једно од основних људских права и отвара нове могућности за комуницирање различитим друштвеним актерима, групама и институцијама, мењајући на тај начин функционисање многих традиционалних форми општења, поставља се питање колико је овај медиј погодан за религијско комуницирање. Да ли је у конкретном случају за институције Српске православне цркве и њене гласноговорнике ово адекватан простор за преношење религијске поруке и какву форму она у њему добија?

У онлајн простору религијске организације делују на различите начине. Сва та деловања, Кристофер Хеланд поделио је на две велике групе. Наиме, он је увео терминолошку разлику између онлајн религије и религије онлајн. Сајтови са високим нивоом интеракције и двосмерне комуникације, као и са мало или нимало ограничавања слободе представљају онлајн религију, док религију онлајн карактерише статична презентација, на којима није могућа интеракција и религијско присуство које има сврху преношења информација, текстова, докумената и слично (Helland, 2005: 1). Према њему, постоји коресподенција између официјелних религијских сајтова и религије онлајн и неофицијелних верских презентација и онлајн религије (Исто).

\footnotetext{
${ }^{5}$ Видети на: Закон о електронским медијима, доступно на: http://www.parlament. gov.rs/upload/archive/files/cir/pdf/zakoni/2014/2512-14.pdf, приступљено 25. 8. 2016. године.

${ }^{6}$ Погледати више на: http://www.politika.rs/scc/clanak/316638/SPC-zeli-da-se-vidii-na-kablovskoj-televiziji, приступљено 25. 8. 2016. године.
} 
Стога, од онлајн религије се очекује активна улога сурфера у религијским праксама попут молитви, различитим врстама ритуала, саветовања и слично, док религију онлајн интернет корисници пре свега користе за сазнавање информација. Иако у Србији коришћење интернета као медија за верску комуникацију није развијено као у западној Европи и Америци, све већа компјутерска писменост допринела је афирмативном ставу наше цркве према овој појави.

Српска православна црква се у процес комуницирања путем интернета укључује 2004. године, када оснива свој сајт. Од тада, сајт је једном промењен, односно 2013. године направљена је нова, живописнија презентација организована у облику триптиха који у средишњем делу доноси актуелне информације о црквеном животу и активностима великодостојника. На сајту се, поред тога, могу наћи саопштење црквених поглавара, вести из хришћанског света, информације о активностима цркве и распореду богослужења, религијски текстови, видео-материјал, материјали везани за историју, учења цркве, о обредима и обичајима, затим активности везане за науку и културу, духовне мисли црквених великодостојника, свети списи, архива ранијих садржаја и сличне објаве од значаја за цркву и хришћански живот.

Поред званичног сајта Српске православне цркве, сајтове имају и епархије, а унутар њих и друге верске организације попут манастира, храмова, цркава, канцеларије за веронауку, пословнопродајних центара, хуманитарних организација и слично.

Српска православна црква присутна је на интернету и у облику налога на друштвеним мрежама. Заступљени су профили како организација тако и свештених лица која делују унутар СПЦ. Ово говори о различитим могућностима за учешће верника̂ у онлајн активностима Цркве.

Уколико се вратимо на установљену терминолошку поделу, може се закључити да је, када је у питању деловање Српске православне цркве на интернету, заправо реч о религији онлајн. Наиме, сајтови не пружају могућност онлајн слушања литургија̂, учестовања у обредима попут крштења̂, венчања̂ и сличним церемонијама, нема интерактивних елемената као што су тзв. chat rooms, дискусионе групе, блогови и форуми на којима је комуникација и размена садржаја активна. Контакт је омогућен преко мејлова и телефона, што и даље остаје у терминолошкој одредници религије онлајн.

Већи степен интеракције заступљен је преко друштвених мрежа. Комуникација је овде непосреднија и отворенија. Поред различи-

${ }^{7}$ Погледати више на: http://www.spc.rs/sr/linkovi/linkovi_eparhija, приступљено 22. 8. 2016. године. 
тих информација о активностима манастира, цркава и других верских организација, верници могу поставити питања, учествовати у дискусији са другим верницима и/или свештеним лицима, „делити” материјале (писане, аудио и визуелне), говорити о својим личним утисцима и верским искуствима, затражити савет или замолити свештеника да се за њих помоли, организовати различите врсте акција и друго. Заправо, друштвене мреже налазе се између религије онлајн и онлајн религије, јер је одређена интеракција могућа, али пре свега има сврху долажења до информација и њихове размене. То значи да се друштвене мреже не користе за упражњавање верских активности као што су литургије, молитве, обреди, церемоније.

\section{ИЗАЗОВИ ФЕНОМЕНА РЕЛИГИЈЕ НА ИНТЕРНЕТУ}

Онлајн присуство отвара нека нова питања за религију. Пре свега, поставља се питање традиционалног религијског ауторитета. Услед све веће доступности садржаја, угрожава се једнозначност религијске поруке. Могућност да се она тумачи на различите начине најбоље се види на примеру ислама. Спајање терористичких активности њених „верника” са учењем о самој религији и оним што она представља допринело је негативном публицитету муслиманске вере и њеног доживљавања као погрешне, насилне, искључиве. Међутим, како каже Карен Армстронг, ауторка књиге Поља крви. Религија и историја насиља, „тероризам нема никакве везе с Мухамедом у мјери истој у којој крсташки ратови немају никакве везе с Исусом; нема ничега у исламу што ислам чини насилнијим у односу на хришћанство". Тумачење вере кроз деловање њених чланова није исправан пут и иако се такав садржај најчешће може наћи на интернету, он не поседује снагу традиционалних религијских ауторитета за тумачење светих списа.

Када је реч о деловању Српске православне цркве на интернету, као што је већ напоменуто, поред званичног сајта, постоје и други самостални сајтови епархија, парохија, манастира, црквених општина итд. Они су, у складу са могућностима сваке цркве, покретани у различито време и разликују се по нивоу уређености представљања, актуелности, количини информација. Међутим, како спречити ситуацију у којој свако може себе представити као епархиjу, манастир, парохију и тиме неадекватно тумачити поруке вере, користити име СПЦ за лажне апеле за помоћ, уносити немир, ширити поруке мржње према припадницима других вера и слично? Мо-

8 Погледати више на: http://www.nieuwwij.nl/english/karen-armstrong-nothingislam-violent-christianity/, приступљено 30. 8. 2016. године. 
гућност да поруке вере путем интернета шаље и интерпретира свако отвара питање аутентичности истих.

Поред ове негативне стране, коју доноси флуидност интернет простора над којим нико нема контролу, позитиван помак представља активност Српске православне цркве на новом сајту, којом је сужена могућност таквог лажног представљена. Наиме, на званичној интернет презентацији СПЦ обједињени су сви сајтови институција које делују у оквиру Српске православне цркве. ${ }^{9}$ Тако је створен њихов јединствен наступ на интернету, где корисници могу проверити сваки сумњив сајт упоређујући га са линковима на званичној страници СПЦ. Ипак, друштвене мреже не улазе у ово поље и могло би се рећи да представљају посебан феномен религијског деловања у онлајн простору које отвара много сложених питања, па као такве захтевају детаљније истраживање и приступ који превазилази сврху овог рада.

Још један сегмент на интернету може нанети велику штету мисији Цркве, а то је проблем индивидуализације црквених информативних сајтова. Корисницима, односно посетиоцима сајтова, није увек лако разграничити личне ставове појединаца (ако су они свештеници) од става Цркве по неком питању. Зато је важна обазривост корисника̂, али пре свега одговорност црквених гласноговорника о (не)изједначавању личног мишљења са званичним црквеним ставовима. Ово је нарочито важно када се ради о темама о којима не постоји јединствен став унутар Цркве (нпр. донорство органа, еутаназија и друго).

Говорећи о негативним странама интернета, теоретичари често помињу конкуренцију и надметање између два света: реалног и виртуелног. Заступљено је схватање да, услед онлајн задовољавања религијских потреба, присуство у цркви није неопходно. Међутим, деловање Српске православне цркве у онлајн простору није таквог карактера да би заменило физичко присуство верника у цркви. Традиционално, СПЦ и њене институције највише полажу на усмену проповед и литургију, што су облици комуницирања којима се преносе и главне поруке Цркве (Стојковић-Радојковић, 2009: 121). Све док интернет остаје првенствено коришћен зарад информисања, односно у терминима религије онлајн, која не укључује религијске праксе, он не може угрозити физички простор Цркве у коме се веза са Богом на нашим просторима традиционално и првенствено остваривала.

И док нови медији служе као још једна могућност долажења до информација, те пружају другачији начин религијског комуници-

9 Погледати више на: http://www.spc.rs/sr/linkovi/linkovi_eparhija, приступљено 22. 8. 2016. године. 
рања (масовна и јавна комуникација), усменом црквеном речју одувек се на најбољи начин преносило значење и смисао светих списа.

\section{ЗАКЉУЧАК}

Српска православна црква као агенс информационо-комуникационог система делује на различите начине. Њен утицај првенствено се оставарује путем међусобне комуникације свештених лица̂ и верника̂. Поред тога, црквена реч преноси се и преко штампаних публикација, књига и других верских материјала. Новине и часописи оснивају се у складу са одлуком сваке појединачне епархије, односно локалне цркве и њихов број зависи од средстава које су ове институције спремне да издвоје за такву издавачку делатност. Најчешће се ради о месечним издањима часописа.

Са појавом електронских медија, моћ преношења информација и њиховог утицаја на примаоце значајно је повећана. То су уочили и гласноговорници Српске православне цркве, те се она укључује у процесе масовног комуницирања путем ових медија. Поред повремених емисија верског карактера и простора у медијима који Црква добија за време великих православних празника, крајем двадесетог века, СПЦ оснива и сопствени радио. Значајно за њено деловање је и могућност коју је стекла новим Законом о електронским медијима из 2014. године, а којим је дозвољено да оснује и радио и телевизије на регионалном нивоу (уместо само на локалном, што је био случај до тада). Данас у Србији делује петнаестак радио-станица Српске православне цркве и једна телевизија (ТВ Храм), чији садржај гледаоци могу пратити само путем интернета.

Присуство Српске православне цркве у онлајн простору огледа се кроз сајтове и друштвене мреже. Званични сајт СПЦ је у том смислу најинформативнији и на њему се могу наћи подаци о свим другим интернет презентацијама који делују унутар СПЦ - сајтови епархија, локалних цркава, манастира, радија и сл. Интернет је због своје глобалности и флуидности отворио одређена питања за религију, али и олакшао верницима долажење до информација, црквених списа и друго.

Време мења и средства, те тако информисање и деловање преко нових облика комуникације делује као логичан след. Стога, присуство Српске православне цркве у медијима, штампаним, електронским и на интернету - јесте нужност савременог доба које не води битку са прошлошћу и традиционалним присуством међу црквеним зидовима, већ „традиционално” остаје примарни облик религијских пракси, а нови медији служе као додатни извор информација. Они носе изазове, али не угрожавају старе начине упражњавања вере, те нису заменили и не могу заменити комуникацију свештеника̂ и верника̂. 


\title{
ЛИТЕРАТУРА
}

Brown, R. M. (1973): [Religion and Violence.]. Philadelphia: Westminster Vujaklija, M., (2006): [Lexicon of foreign words and expressions.]. Belgrade: Education

Danicic, Dj., (2005): [The Holy Bible - the Old and New Testament.].Sabac Valjevo - Belgrade: The Voice of the Church

Dirkem, E., (1977): [The elementary Forms of religious Life.]. New York: Free Press

Morgan,D., (2005): [Sacred Gaze: Religious Visual Culture in Theory and Practice.]. Los Angeles and London: Berkeley

Radojkovic, M., Stojkovic, Б.,(2009):[ Information-communication systems.]. Belgrade: Faculty of Political Science

Stewart, H., (2006): [Religion in the Media Age.]. London: Routledge

Hjarvard,S., (2008): Introduction: [The mediatisation of religion: enchantment, media and popular culture. ]. New York: Northern Lights Volume 6

Christopher,H., (2005): [Online Religion as Lived Religion: Methodological Issues in the Study of Religious Participation on the Internet.]. Heidelberg: Online Heidelberg Journal of Religions on the Internet

\section{INTERNET SOURCES}

http://www.spc.rs/

http://www.nieuwwij.nl/english/karen-armstrong-nothing-islam-violent-christianity/ http://www.poreklo.rs/2013/01/04/na-dana\%C5\%A1nji-dan-\%C5\%A1tampana-prvaknjiga-na-srpskom-oktoih-prvoglasnik/

http://www.parlament.gov.rs/upload/archive/files/cir/pdf/zakoni/2014/2512-14.pdf

http://www.politika.rs/scc/clanak/316638/SPC-zeli-da-se-vidi-i-na-kablovskojteleviziji

http://www.svetigora.com/

http://www.serbianorthodoxchurch.net/historyofchurch/book1/book1.swf

http://www.eparhijavranjska.org/wradio/default.asp

\section{THE SERBIAN ORTHODOX CHURCH AS AN AGENT COMMUNICATION LANGUAGE}

\author{
Jasna Parlić Božović ${ }^{1}$, Dragana Božović ${ }^{2}$ \\ ${ }^{1}$ University of Priština, Faculty of Philosophy in Kosovska Mitrovica, \\ Kosovska Mitrovica, Serbia \\ ${ }^{2}$ University of Belgrade, Faculty of Political Sciences, Belgrade, Serbia
}

\section{Summary}

The Serbian Orthodox Church as an agent of information-communication system acts in different ways. Its influence is primarily achieved through the mutual communication between the clergy and believers. In addition, the church word is also transmitted through printed publications, books, and other religious materials. Newspapers and magazines are established in accordance with the decision of each individual eparchy (diocese) or local church, and their number depends on the funds that 
these institutions are prepared or willing to allocate for such publishing activity. These are mostly monthly issues of the magazine.

With the emergence of electronic media, the power of transmission information and its impact on the recipients has significantly increased. This was also noticed by the Serbian Orthodox Church spokesmen and the church is being involved in the processes of mass communication through these media. In addition to the occasional religious broadcasting and church has its own media setting during the Orthodox holidays, at the end of the twentieth century, the SOC had an opportunity to establish its own radio program. Significant for its performance, the church had the possibility to acquire exclusive rights with the new Electronic Media Law and Regulation allowing to establish radio and television at the regional level (instead of only on the local ones, which was the case by then).Today in Serbia, The Serbian Orthodox Church already operates 15 radio stations and launched a television station, TV Hram ("TV Temple") that is available only online.

The internet presence of the Serbian Orthodox Church is reflected through websites and social networks. The official website of the SOC is in this sense the most informative and on it you can find information about all other websites that operate within the SOC - diocesan sites, local churches, monasteries, radios, etc.

Because of its globality and fluidity, the Internet has opened up certain issues referring to religion, but it also facilitates believers getting information, ecclesiastical writings, and more.

Time changes the means as well, and thus informing and acting through new forms of communication acts as a logical trail. Therefore, the presence of the Serbian Orthodox Church in media both print and electronic and online - is the necessity of the modern age that does not lead the battle with the past and the traditional presence among the church walls, but "traditionally" remains the primary form of religious practice, and new media serve as an additional source of information. They carry challenges, but do not endanger the old ways of practicing religion and have not replaced them and cannot replace the communication between the clergy and believers. 